\title{
Naltrexone-Induced LH Release in Ovariectomized Estrogen-Primed Rats
}

\author{
TAKashi HIGUCHI and Masazumi KAWAKAMI
}

\author{
Department of Physiology, Yokohama City University School of \\ Medicine, Yokohama 232, Japan
}

\begin{abstract}
In order to investigate the physiological role of endogenous opioid substances in the regulation of gonadotropin secretion, we studied the effect of Naltrexone (Nalt), a morphine antagonist, on serum luteinizing hormone (LH) concentrations in ovariectomized estrogen-treated rats. The site of action of Nalt and its interaction with other putative neurotransmitters on LH secretion were investigated in hypothalamic deafferentated rats and in animals treated with pharmacological inhibitors of the actions of neurotransmitter substances. Nalt injection increased serum LH levels at doses 0.08 to $2 \mathrm{mg} / \mathrm{kg} \mathrm{BW}$. The response was dose-dependent but higher doses of Nalt had less effect. In inducing this response pattern, mediobasal connection between the anterior hypothalamus and the mediobasal hypothalamus was essential, but posterior input to the mediobasal hypothalamus was not necessary. Excepting $\alpha$-adrenergic blocker, all the blockers used, i.e $\beta$-adrenergic, serotonin, dopamine and acetylcholine blockers were effective in eliminating the LH release evoked by Nalt injection. These results suggest that endogenous opioid substance might inhibit LH secretion tonically through aminergic and/or cholinergic neurons and that the mediobasal neural connections to the mediobasal hypothalamus are indispensable for this inhibition.
\end{abstract}

In 1955 Barraclough and Sawyer observed inhibition of ovulation by morphine injection in female rats, which was explained as a resuit of blocking the pituitary gonadotropin release by morphine. Their result was confirmed by the determination of serum gonadotropin concentrations using radioimmunoassay (Muraki et al., 1977). The anti-ovulatory effect of morphine until recently has been attributed to its pharmacological action, like that of such anesthetics as pentobarbital. Since endogenous opioid substances and their receptors were discovered (Hughes et al., 1975) and opioid substances were found to be abundant in the hypothalamus (Hong et al., 1977)

Received October, 31, 1980. it may be possible that these opioid substances are physiologically involved in the regulation of secretion of pituitary hormones including gonadotropins.

In order to investigate this regulatory aspect of endogenous opioid substances, we studied the effect of a specific antagonist of morphine, naltrexone on serum LH levels in ovariectomized estrogon-treated rats. Furthermore, we attempted to elucidate the site of action of the morphine antagonist using neural deafferentation (Halász and Pupp, 1965) and to clarify its interaction with other putative neurotransmitters reported to be involved in the gonadotropin regulation (Gnodde and Schuiling, 1976, Kawakami et al., 1979; Sawyer, 1977), by using their receptor blockers. 


\section{Materials and Methods}

\section{Animals}

Female Wistar rats (180-200 g BW) were housed in a light-controlled (light on 500-1700), air-conditioned room $\left(25 \pm 1^{\circ} \mathrm{C}\right)$ and fed pelleted food (MF, Oriental Kobo, Japan) and tap water ad libitum. They were ovariectomized under ether anesthesia and subjected to the brain operation at least one month after spaying.

Hypothalamic deafferentation was performed according to the method described by Halász and Pupp (5). A Halász knife with a $2.0 \mathrm{~mm}$ radius and 2.0 $\mathrm{mm}$ vertical blade (large knife) or one with a 1.2 $\mathrm{mm}$ radius and $1.2 \mathrm{~mm}$ vertical blade (small knife) was used. The animals were placed in a $2.5 \mathrm{~mm}$ nose down position into the holder of a stereotaxic instrument and the hypothalamus was subjected to the following types of deafferentation. Large anterior deafferentation I: large knife was rotated $180^{\circ}$ at the level of the suprachiasmatic nucleus (guided by König and Klippel's rat brain atlas, 9). Anterior deafferentation II: large knife was rotated $180^{\circ}$ at the level of posterior border of the anterior hypothalamic area. Small anterior deafferentation: small knife was rotated $180^{\circ}$ at the same level as large anterior deafferentation II. Posterior deafferentation: large knife was rotated $180^{\circ}$ at the level of mid-mammillary body. Sham operated animals: large knife was inserted down to the base of the skull in the midsagittal plane without being rotated. The operated animals were used for the Nalt experiment at least one month after surgery. All animals were injected with estradiol benzoate sc. (EB, $5 \mu \mathrm{g})$. An intraatrial cannula was implanted the next day and these rats were placed in individual cages. Two days after EB injection, the rats were injected with Nalt dissolved in physiological saline through the cannulae. At the termination of the experiment the brains were fixed and frozen sections were cut in the frontal plain at $60 \mu$ and were examined histologically to determine the deafferentation sites.

\section{Chemicals}

Chemicals used in the experiment were obtained from the following sources: naltrexone (Endo Labs., Garden City, USA), phentolamine (Chiba Ltd., Basel, Switzerland), phenoxybenzamine (Tokyo Kasei Ind., Tokyo, Japan), propranolol (Sumitomo Chemical Ind., Osaka, Japan), pimozide (Fujisawa Pharmaceutical Co., Osaka, Japan), atropine (Wako Pure Chemical Ind. Ltd., Osaka, Japan), methysergide (Sandoz Ltd., Basel. Switzerland), estradiol benzoate (Teikoku Hormone Mfg. Co., Kawasaki, Japan).

Estradiol benzoate was dissolved in sesame oil.
Pimozide was dissolved in $0.1 \mathrm{M}$ tartaric acid. The other reagents were dissolved in or diluted with physiological saline. These materials were injected through the cannulae except phenoxybenzamine which was administered intraperitonially and atropine and estradiol benzoate which were administered subcutaneously.

\section{Radioimmunoassay}

Blood samples $(0.5 \mathrm{~m} l)$ were taken through intraatrial cannulae just before, and 10, 30, 60 min following Nalt injection. The experiment was performed before noon in order to avoid the spontaneous estrogen-induced afternoon elevation of serum LH. Separated serum was stored at $-20^{\circ} \mathrm{C}$ until assayed. Serum LH concentration was determined by double antibody radioimmunoassay (Niswender et al., 1968) using NIAMDD rat $\mathrm{LH}$ radioimmunoassay kit and anti-ovine $\mathrm{LH}$ serum ( $\mathrm{R}-15$, a generous gift from Dr. G. D. Niswender, Colorado State University, USA). LH levels were expressed in terms of NIHLH-S1. Data were analysed by one way analysis of variance.

\section{Results}

\section{Effect of Nalt on serum LH levels}

Intravenous injection of Nalt in doses of 0.08 to $10 \mathrm{mg} / \mathrm{kg} \quad \mathrm{BW}$ induced a significant $(p<0.01$ or 0.05$)$ increase in serum $\mathrm{LH}$ levels in ovariectomized estrogentreated rats (Table 1). The amount of $\mathrm{LH}$ released within $60 \mathrm{~min}$ after Nalt injection was estimated by the values summing $\triangle \mathrm{LH}$ at 10,30 and $60 \mathrm{~min}$ after Nalt injection. It was increased with increasing doses of Nalt injected up to $2 \mathrm{mg} / \mathrm{kg}$ BW, but the increment was declined by further increasing the doses of Nalt. Moreover, when a larger dose of Nalt was injected, for example $50 \mathrm{mg} / \mathrm{kg} \mathrm{BW}$, the serum LH concentration did not continue to increase.

\section{LH release by Nalt in hypothalamic deafferentated rats}

As shown in Table 2 serum LH levels increased following Nalt $(2 \mathrm{mg} / \mathrm{kg} \mathrm{BW})$ injection in sham operated rats and in those with posterior deafferentation. However, the rats bearing anterior deafferentation II 
Table 1. Dose response relationship between injected naltrexone and released LH

\begin{tabular}{|c|c|c|c|c|c|c|}
\hline \multirow{3}{*}{$\begin{array}{c}\text { Naltrexone } \\
(\mathrm{mg} / \mathrm{kg} \mathrm{BW})\end{array}$} & \multicolumn{4}{|c|}{ Serum LH (ng/mg) } & \multirow[b]{3}{*}{ Significance } & \multirow[b]{3}{*}{ Cumulative $\triangle \mathrm{LH}$} \\
\hline & \multicolumn{4}{|c|}{ Time after naltrexone injection (min) } & & \\
\hline & 0 & 10 & 30 & 60 & & \\
\hline 0 & $2.8 \pm 0.7^{a}$ & $3.0 \pm 0.9$ & $2.9 \pm 0.5$ & $2.7 \pm 0$ & N.S.b & \\
\hline $3.2 \times 10^{-3}$ & $3.2 \pm 1.4$ & $5.1 \pm 1.5$ & $4.0 \pm 1.0$ & $2.4 \pm 0.8$ & N.S. & $1.9 \pm 0.4 \mathrm{c}$ \\
\hline $1.6 \times 10^{-2}$ & $2.9 \pm 0.5$ & $5.2 \pm 0.8$ & $4.7 \pm 1.1$ & $3.6 \pm 0.6$ & N.S. & $4.8 \pm 0.8$ \\
\hline $8 \times 10^{-2}$ & $2.7 \pm 0.3$ & $10.5 \pm 2.5$ & $5.2 \pm 0.8$ & $3.9 \pm 0.8$ & $\mathrm{p}<0.01$ & $11.5 \pm 3.1$ \\
\hline $4 \times 10^{-1}$ & $3.1 \pm 0.7$ & $10.6 \pm 0.8$ & $6.6 \pm 1.1$ & $6.4 \pm 0.9$ & $<0.01$ & $14.3 \pm 3.2$ \\
\hline 2 & $3.1 \pm 0.6$ & $11.0 \pm 1.1$ & $6.8 \pm 0.9$ & $7.4 \pm 1.4$ & $<0.01$ & $15.9 \pm 4.1$ \\
\hline 10 & $1.8 \pm 0.6$ & $7.1 \pm 1.9$ & $6.9 \pm 0.1$ & $4.4 \pm 1.5$ & $<0.05$ & $13.0 \pm 2.9$ \\
\hline 50 & $3.2 \pm 1.1$ & $3.3 \pm 1.1$ & $6.8 \pm 2.7$ & $5.9 \pm 2.9$ & N.S. & $6.3 \pm 2.0$ \\
\hline
\end{tabular}

a: Mean \pm standard error of means $(n=5)$

$b$ : Analysed by one way analysis of variance

c : Estimated amount of $\mathrm{LH}$ released in $60 \mathrm{~min}$

Table 2. Naltrexone-induced ( $2 \mathrm{mg} / \mathrm{kg} \mathrm{BW}) \mathrm{LH}$ release in rats bearing hypothalamic deafferentation

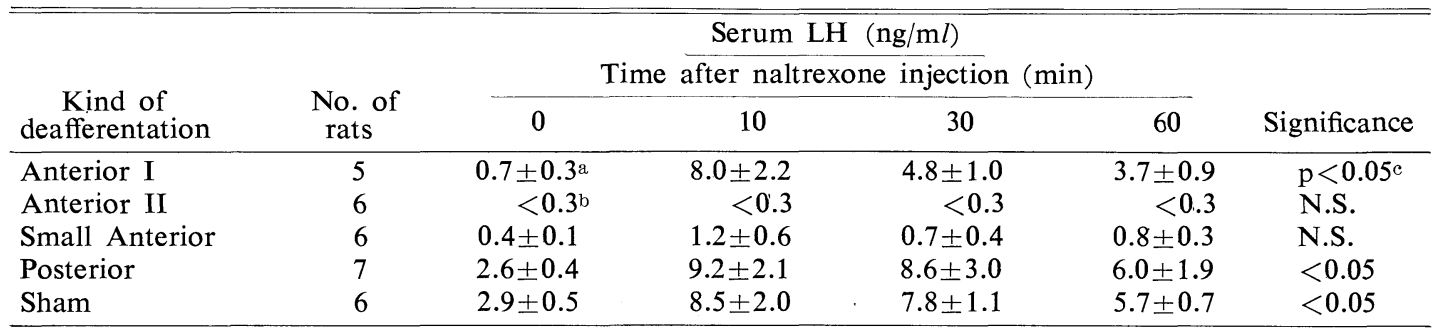

a: Mean \pm standard error of means

$\mathrm{b}$ : Below the sensitivity limit of LH radioimmunoassay

c : Analysed by one way analysis of variance

or small anterior deafferentation did not respond to Nalt injection with an increase in serum concentrations. Nalt evoked LH release in the rats with anterior deafferentation I comparable to that seen in controls.

$L H$ release by Nalt in rats treated with blockers of neurotransmitters (Table 3)

Ovariectomized estrogen-treated rats were injected with receptor blockers of putative neurotransmitters 1 to $2 \mathrm{hrs}$ before Nalt injection. In animals treated with $\alpha$-adrenergic blockers (phentolamine, $10 \mathrm{mg} / \mathrm{kg}$ BW, phenoxybenzamine, $10 \mathrm{mg} / \mathrm{kg} \mathrm{BW}$ )
Nalt injection $(2 \mathrm{mg} / \mathrm{kg} \mathrm{BW})$ induced a significant $(p<0.05)$ increase in serum LH concentrations, though smaller than in saline treated controls. Other receptor blockers; propranolol ( $\beta$-adrenergic blocker, $5 \mathrm{mg} / \mathrm{kg} \mathrm{BW}$ ), pimozide (dopamine receptor blocker, $1 \mathrm{mg} / \mathrm{kg} \mathrm{BW}$ ), methysergide (serotonin receptor blocker, $10 \mathrm{mg} / \mathrm{kg} \mathrm{BW}$ ) and atropine (acetylcholine receptor blocker, $500 \mathrm{mg} / \mathrm{kg} \mathrm{BW}$ ), were effective in blocking the $\mathrm{LH}$ release induced by Nalt injection. 
Table 3. Naltrexone-induced $(2 \mathrm{mg} / \mathrm{kg} \mathrm{BW}) \mathrm{LH}$ release in rats treated with the receptor blockers of putative neurotransmitters

\begin{tabular}{|c|c|c|c|c|c|}
\hline \multirow[b]{3}{*}{ Receptor blockers } & \multicolumn{4}{|c|}{ Serum LH $(\mathrm{ng} / \mathrm{m} l)$} & \multirow[b]{3}{*}{ Significance } \\
\hline & \multicolumn{4}{|c|}{ Time after naltrexone injection ( $\mathrm{min})$} & \\
\hline & 0 & 10 & 30 & 60 & \\
\hline Phentolamine & $1.6 \pm 0.2^{\mathrm{a}}$ & $4.0 \pm 0.6$ & $3.2 \pm 0.6$ & $3.0 \pm 0.4$ & $\mathrm{p}<0.05^{b}$ \\
\hline Phenoxybenzamine & $1.7 \pm 0.2$ & $4.8 \pm 1.2$ & $4.4 \pm 0.7$ & $2.7 \pm 0.4$ & $<0.05$ \\
\hline Propranolol & $1.8 \pm 0.3$ & $1.9 \pm 0.3$ & $1.9 \pm 0.2$ & $2.4 \pm 0.8$ & N.S. \\
\hline Pimozide & $1.5 \pm 0.4$ & $3.7 \pm 0.6$ & $1.7 \pm 0.3$ & $1.8 \pm 0.3$ & N.S. \\
\hline Atropine & $1.8 \pm 0.2$ & $2.1 \pm 0.3$ & $3.4 \pm 0.5$ & $1.9 \pm 0.4$ & N.S. \\
\hline Methysergide & $1 \cdot 9 \pm 0.3$ & $2.2 \pm 0.5$ & $2.1 \pm 0.2$ & $1.9 \pm 0.2$ & N.S. \\
\hline Control & $2.5 \pm 0.4$ & $11.5 \pm 3.1$ & $7.1 \pm 2.1$ & $5.1 \pm 1.1$ & $<0.01$ \\
\hline
\end{tabular}

a: Mean \pm standard error of means $(n=6)$

$b$ : Analyzed by one way analysis of variance

\section{Discussion}

Observations made in this study confirmed the stimulatory effect of opioid antagonist on LH release in estrogen-treated ovariectomized rats as reported in human males (Mendelson et al., 1978), male rats (Bruni et al., 1977) and infantile female rats (Blank et al., 1979; Ieiri et al., 1979). The opioid antagonist, naloxone, however, failed to facilitate LH secretion in adult female rats at any stage of the estrous cycle (Blank et al., 1979). The reason why opioid antagonist can induce LH release in ovariectomized estrogen-treated rats or intact males, but not in intact female rats, is not clear. Estrogen treatment blocks the $\mathrm{LH}$ response to naloxone in prepubertal female rats (Blank et al., 1979), whereas estrogen in adult ovariectomized rats in this study sensitized them to respond to naltrexeone. Developmental changes in the brain or gonads may explain these differeneces. Further study is needed to clarify these points.

Morphine is known to inhibit proestrous LH surge and ovulation (Barraclough and Sawyer, 1955; Muraki et al., 1977). This inhibitory effect of morphine appears to be due to its suppressing action on LH-RH release through endogenous opioid receptors. In addition to these results, present observa- tions indicate that endogenous opioid substance tonically suppresses $\mathrm{LH}$ release and that Nalt antagonizes the opioid substance to raise serum LH levels. The does response relationship between the amount of $\mathrm{LH}$ released and the amount of Nalt injected was not simple. The released amount and peak level of $\mathrm{LH}$ after Nalt injection increased dose-dependently uo to $2 \mathrm{mg} / \mathrm{kg}$ BW but declined thereafter. A higher doses of Nalt may have other effects than blocking opioid receptors. We observed seizure activity lasting several seconds in rats injected with $50 \mathrm{mg} / \mathrm{kg} \mathrm{BW}$ Nalt, which may be related to the inability of large doses of Nalt to increase in serum LH concentrations.

From the results obtained in the rats with partial neural deafferentation of the hypothalamus, Nalt-induced LH release dose not occur following anterior deafferentation II or small anterior deafferentation but occurs following anterior I or posterior deafferentation. Posterior afferents to the mediobasal hypothalamus therefore seem to be unnecessary for the LH release by Nalt, but the neural connection between the anterior hypothalamus and the mediobasal region is indispensable. Since the small anterior cut was as effective as anterior deafferentation II in blocking Nalt-induced LH releesa, the indispensable neural connection to the mediobasal hypothalamus for the $\mathbf{L H}$ 
release may lie in the medial basal part of this area. Since anterior deafferentation II reduced $\mathrm{LH}$ concentrations in serum and pituitary and $\mathrm{LH}$ responsiveness to LH-RH stimulation (Table 2 and unpublished data), and that immunohistochemical study revealed LH-RH perikarya in the preoptic area and the septum (Barry et al., 1973), these cuts may interrupt the axons of the LH-RH neurons, having their perikarya anterior to the deafferentation II. The opioid antagonist might act at the level of the anterior hypothalamus or the posterior part of the medial preoptic area. And after neural deafferentation between the anterior and the mediobasal hypothalamus, the stimulatory input for LH-RH release induced by the opioid antagonist was untable to reach the mediobasal hypothalamus any more. But there is a possibility that Nalt might act at the mediobasal hypothalamus to induce LH-RH release without a consequent $\mathrm{LH}$ rise because of the lower responsiveness of the pituitary to LH-RH or lower releasable content of LH-RH in the mediobasal hypothalamus due to anterior deafferentation (Kalra et al., 1977).

Several putative neurotransmitters are thought to be involved in the regulation of LH secretion. The receptor blockers of these neurotransmitters were reported to suppress the elevated serum $\mathrm{LH}$ in ovariectomized rats (Gnodde and Schuiling, 1976) and to inhibit $\mathrm{LH}$ release induced by sex steroid hormones in ovariectomized rats (Kawakami et al., 1979). In our study all the blockers, except $\alpha$-adrenergic blocker, eliminated the facilitating effect of Nalt on the release of LH. Since endogenous opioid substances were reported to influence the release or metabolism of noradrenaline (Taube et al., 1976), dopamine (Subramanian et al., 1977; Biggio et al., 1978), serotonin (Van Loon and De Souza, 1978) and acetylcholine (Subramanian et al., 1977; Van Loon and De Souza, 1978; Moroni et al., 1977), it seems possible that endogenous opioid substances exert their inhibitory effect on $\mathrm{LH}$ secretion via these aminergic or cholinergic neurons.

In summary our results suggest that endogenous opioid substances tonically inhibit $\mathrm{LH}$ release via aminergic and/or cholinergic neurons and that the anteriormediobasal neural connections to the mediobasal hypothalamus are indispensable for this inhibition.

\section{Acknowledgements}

The authors are indebted to NIAMDD, Dr. G.D. Niswender, Colorado State University USA and Dr. K. Wakabayashi, Gunma University, Japan for supplying radioimmunoassay materials. We also thank Drs. H. Weidmann, and E. Flückinger (Sandoz Ltd., Basel, Switzerland) and Endo Labs (Garden City, USA) for generous gift of methysergide and naltrexone.

We are grateful to Dr. O. P. Tandon for preparing the manuscript. This work was supported by a Grant-in-Aid for Encouragement of Young Scientist from the Ministry of Education, Science and Culture of Japan (477100).

\section{References}

Barraclough, C. A., and C. H. Sawyer (1955). Inhibition of the release of pituitary hormone in the rat by morphihe. Endocrinology 57, 329-337.

Barry, J., M. P. Dubois, and P. Poulain (1973). LRF producing cells of the mammalian hypothalamus. Z. Zellforsch. 146, 351-366.

Biggio, G., M. Casu, M. G. Corda, C. DiBello and G. L. Gessa (1978). Stimulation of dopamine synthesis in caudate nucleus by intrastriatal enkephalins and antagonism by naloxone. Science 200 , $552-554$

Blank, M. S., A. E. Panerai, and M. G. Friesen (1979). Opioid peptides modulate luteinizing hormone secretion during sexual matulation. Science 203, 1129-1131.

Bruni, J. F., D. Van Vugt, S. Marshall, and J. Meites (1977). Effects of naloxone, morphine and methionine enkephalin on serum prolactin, luteinizing hormone, follicle stimulating hormone, thyroid stimulating hormone and growth hormone. Life Sci. 12, 461-466.

Gnodde, H. P., and G. A. Schuiling (1976). Involvement of catecholaminergic and cholinergic me- 
chanism in the pulsatile release of LH in the longterm ovariectomized rat, Neuroendocrinology 20, 212-223.

Gudelsky, G. A. and J. C. Porter (1979). Morphineand opioid peptide-induced inhibition of the release of dopamine from tuberoinfundibular neurons. Life Sci. 25, 1697-1702.

Halász, B. and L. Pupp (1965). Hormone secretion of the anterior pituitary gland after physical interruption of all nervous pathways to the hypophysiotrophic area. Endocrinology 77, 553-562.

Hong, J. S., H. Y. T. Tang, W. Fratta, and E. Costa (1977). Determination of methionine enkephalin in discrete regions of rat brain. Brain Res 134, 383-386.

Hughes, J., T. W. Smith, H. W. Kosterlitz, L. A. Fothergill, B. A. Morgan, and H. R. Morris (1975). Identification of two related pentapeptides from the brain with potent oiate agonist activity. Nature 258, 577-579.

Ieiri, T., H. T. Chen, and J. Meites (1979). Effects of morphine and naloxone on serum levels of luteinizing hormone and prolactin in prepubertal male and female rats. Neuroendocrinology 29, 288292.

Jhamandas, K., J. Sawynok, and M. Sutak (1977). Enkephalin effects on release of brain acetylcholine. Nature 269, 433-434.

Kalra, S. P., P. S. Kalra, and E. O. Mitchell (1977). Differential response of luteinizing hormone-releasing hormone in the basal hypothalamus aud the preoptic area following anterior hypothalamic deafferentation and/or castration in male rats. Endocrinology 100, 201-204.

Kawakami, M., J. Arita, F. Kimura, and R. Hayashi (1979). The stimulatory roles of catecholamine and acetylcholine in the regulation of gonadotropin release in ovariectomized estrogen-primed rats.
Endocrinol Japon. 26, 275-284.

König, J. F. R., and R. A. Klippel, The rat brain. A stereotaxic atlas of the forebrain and lower parts of the brain stem, Williams and Wilkins Co., Baltimore (1963).

Mendelson, J. M., J. Ellingboe, J. C. Keuhnle, and N. K. Mello (1978). Effects of naltrexone on mood and neuroendocrine function in normal adult males. Psychoneuroendocrinology 3, 231-236.

Moroni, F., D. L. Cheney, and E. Costa (1977). $\beta$ Endorphin inhibits ACh turnover in nuclei of rat brain. Nature 267, 267-268.

Muraki, T., Y. Tokunaga, and T. Makino (1977). Effects of morphine and naloxone on serum LH, FSH and prolactin levels and hypothalamic content of LH-RF in proestrous rats. Endocrinol Japon. 24, 313-315.

Niswender, G. D., A. R. Midgley, Jr., S. E. Monroe, and L. E. Reichert, Jr. (1968). Radioimmunoassay for rat luteinizing hormone with antiovine LH serum and ovine LH-131I. Proc. Soc. Exp. Biol. Med. 128, 807-811.

Sawyer, C. H. Brain catecholamines and pituitaryovarian function, (1977). Biol. Acad. Sci. Hung. 28, 11-23.

Subramanian, N., P. Mitznegg, W. Sprügel, W. Domschke, S. Domschke, E. Wünsch, and L. Demling (1977). Influence of enkephalin on $\mathrm{K} \dagger$ -evoked efflux of putative neurotransmitters in rats brain. Naunyn-Schmierdeberg's Arch. Pharmacol. 299, 163-165.

Taube, H. D., E. Borowski, T. Endo, and K. Starke (1976). Enkephalin: a potential modulator of noradrenaline release in rat brain. Europ. J. Pharmacol. 38, 377-380.

Van Loon, G. R., and E. B. De Souza (1978). Effects of $\beta$-endorphin on brain serotonin metabolism, Life Sci. 23, 971-978. 